\title{
Comparison Inventory of UNESCO World Heritage Villages: Kampung Morten, Melaka and Ogimachi Village, Shirakawa-Go, Gifu
}

\author{
Syakir Amir*, Lukman Hakim, Nurul Emmira Natasya Nordin, Nur Syazwani Rosli, \\ Nur Adila Mohamad Shokri, Nur Zafirah Mohd Salleh, Khairul Anuar Mohamad Pisol, \\ Abdul Aruf Ramlan \\ Kulliyyah of Architecture and Environmental Design, \\ International Islamic University Malaysia \\ *Corresponding author. E-mail: syakiramir@iium.edu.my
}

\begin{abstract}
Received: 21 Apr 2020

Reviewed: 7 May 2020

Accepted: 20 June 2020

Heritage villages within UNESCO World Heritage Sites are often associated with natural, cultural and social characteristics of the urban and sub-urban fabric of the previous era. Kampung Morten, Melaka and Ogimachi Village, Shirakawa-go, Gifu each constitute important historical evidence in and of themselves. The villages have existed since the 11th century and each has a strong sense of community. Their traditional social systems and lifestyle customs have sustained the traditional houses and their associated historic environments. The integrity of the nominated areas in both villages is related to the presence of all the elements necessary to express their outstanding example of type of building, architectural or technological ensemble or landscape which illustrates their significant stages in human history. The villages have retained their authenticity; listed monuments and sites have been restored with appropriate treatments regarding design, materials, methodologies, techniques and workmanship, in accordance with conservation guidelines and principles. Thus, this paper seeks to understand and identify the characteristics of these historical villages by focusing on the use of traditional materials and techniques, as well as their viewpoints of setting, function, and UNESCO management systems.
\end{abstract}

Keywords: Heritage village, UNESCO World Heritage Sites, Kampung Morten, Ogimachi Village

\section{INTRODUCTION}

Kampung Morten, Melaka is a remarkable example of historic colonial town on the Straits of Malacca that demonstrate a succession of historical and cultural influences arising from their former function as trading ports linking East and West. They are the most complete surviving historic city centre on the Straits of Malacca. Ogimachi Village, Shirakawa-go on the other hand, located in a mountainous region that was cut off from the rest of the world for a long period of time, these villages with their Gassho-style houses subsisted on the cultivation of mulberry trees and the rearing of silkworms where the large houses with their steeply pitched thatched roofs are the only examples of their kind in Japan.

To be included on UNESCO's World Heritage List, sites must be of Outstanding Universal Value (OUV) and meet at least one of the following ten selection criteria and the historic villages of Shirakawa-go and Kampung. Morten shown outstanding examples of traditional human settlements that are perfectly adapted to their environment and their social and economic. Thus, finding the balance between cultural heritage and the need to preserve the natural heritage are very crucial. This paper aims 
to understand these heritage villages of over time in order to identify the best practices, strategies, actions and measures applied for the conservation of their universal value with a particular focus on sustainability on maintaining the historical characteristics. The management systems of the heritage villages of UNESCO sites were studied by the comparison of nomination files and management plans.

\section{LITERATURE REVIEW}

The purpose of UNESCO mission in 1972 to create and recognize a world heritage list was to ensure the preservation, safeguarding and protection of the heritage sites, for future generation (Kim, Wong, \& Cho, 2007; Canale, Simone, Maio \& Parenti, 2019). It is also to provide assistance to the sites that are in danger (Frey \& Steiner, 2011). UNESCO World Heritage Sites includes heritage and natural features such as forest and mountains and man- made elements including monuments, buildings and cities. The values of the site must be universal and outstanding where the best representative and can be acknowledged as general or worldwide (Adie, Ashton, Hall, \& Girish, 2018). Historically, the cultural practice and preferences of various culture created an impact toward development of Kampung Morten and Ogimachi Village WHS. Furthermore, the landscape expresses the significance of the history and depicts the intangible aspects of the urban's cultural landscape.

\section{Study Area}

This research will be focusing at two different study areas; Kampung Morten, Melaka and Ogimachi Village, Shirakawa-go. Kampung Morten is located at the Center of Historic City of Melaka. Kampung Morten has evolved become a hub for Melaka's tourism activities since being declared a heritage village under the state's Preservation and Conservation Enactment in 1989. Meanwhile, known as the "White River Old District," Ogimachi Village, Shirakawa-go is located in the village of Shirakawa, located in the Shogawa river valley. Table 1 below presents the summary of sites profile of both Kampung Morten and Ogimachi Village.

Table 1. Summary of Sites Profile: Kampung Morten and Ogimachi Village

\begin{tabular}{lcc}
\hline \multicolumn{1}{c}{ Indicators } & Kampung Morten & Ogimachi Village \\
\hline Area (acres) & 12.4 & 170 \\
Population & 900 & 1630 \\
Country & Malaysia & Japan \\
Prefecture/State & Melaka & Gifu \\
Year built & 1921 & $1800 \mathrm{~s}$ \\
Climate & 2 seasons & 4 seasons \\
No. of houses & 90 traditional houses and a mosque & 300 traditional houses \\
UNESCO recognition & July 2008 & December 1995 \\
UNESCO criterias & Criteria (ii), criteria (iii) and criteria (iv) & Criteria (iv) and criteria (v) \\
\hline
\end{tabular}

\section{METHODOLOGY}

Site inventory method is the practical ways of collecting data on site. The observation has been conducted during the site visit at Kampung Morten in May 2019 and Shirakawa-go in January 2019. An inventory survey that comprises five main elements, namely house structure, supporting facilities, tourism attractions and tourism activities are recorded. As suggested by Butrina, et al, 2020, inventory survey is supported by the semi-structured interviews with the local community for validation and verification purposes. Next, the data will be analyzed through content analysis where the information regarding Kampung Morten and Ogimachi Village will be compared thoroughly. 


\section{ANALYSIS AND FINDINGS}

There are few scopes of study for both villages; housing structures, supporting facilities, tourism activities, tourist attraction and UNESCO management. Next sub-sections present the comparison of scopes between these two villages.

\section{House Structure}

The study found that there is significance to the definition Azlaini (2013) that the Malay house itself is a piece of furniture. The furniture presents a manifestation of the unique culture and the way of life of the Malay. It has shown the identity and the reason behind the form and function. It may simple but practical. In Japan, municipalities are taking the opinions of the communities in designating the preservation districts. Therefore, municipalities are the central figures in promoting a preservation project, in terms of giving permission for the alteration of the present state, repairs and enhancement within preservation districts. As many of them have roofs made of plant materials like thatch which is it extremely vulnerable to fire. For this reason, the Agency for Cultural Affairs provides necessary subsidies for the owners or custodians bodies to install or repair fire-preservation facilities and other necessary disaster prevention system. Table 2 below presents the summary of housing structure for Kampung Morten and Ogimachi Village.

Table 2. Housing structure

\begin{tabular}{lcc}
\hline \multicolumn{1}{c}{ Components } & $\begin{array}{c}\text { Kampung Morten } \\
\text { House Structure }\end{array}$ & Ogimachi Village \\
\hline Types of house & $\begin{array}{c}\text { Traditional house, Malay } \\
\text { architecture }\end{array}$ & Gassho-style house \\
Level of house & Single storey & 3 to 5 levels \\
Roof materials & Gable roof & $\begin{array}{c}\text { Straw ropes and 'neso' ropes, a rope } \\
\text { made from mansaku trees }\end{array}$ \\
Fence & Open, no fence & Open, no fence. \\
Function of attic & Storage for larger tools & Space for industry \\
Verandah & Serve as formal space & Raised wooden veranda \\
\hline
\end{tabular}

Source: Site inventory, 2019

Kampung Morten is situated in the middle of Melaka city that it still retains the traditional values, culture and features such as home design, decoration, landscape and others. Most of the houses were built from the local timber and single-storey structure. The forms of Malay house are shown on the roof part. Most of the Kampung Morten houses are categorized in the long roof design. The ridge board is long straight and mounted horizontally elongated. The side walls are mounted roof gable. The house uses gable roof type. Under the gable roof located hidden space known the loteng or loft. Similar with other Malay traditional village, Kampung Morten does not have any proper fencing between the houses. The site inventory and observation is verified by one of the house owner who have direct experience with the spatial activities. Most of the houses were designed for the front zone - anjung (covered porch) and serambi (veranda) that serve as a formal space. From a religious perspective, the anjung and serambi usually serve for formal activities such as weddings, ritual prayer and circumcision area, while, serambi serves as a prayer and study area.

Ogimachi Village has a style of building known as "gabled gassho style", with its triangular shaped eaves resembling an open book propped up on its covers, is ideally adapted to the natural conditions in Shirakawa-go, characterized by great weights of snow deposited during heavy snowfalls. Additionally, there are no fences between the houses, giving it an open atmosphere. The structures face to the north and south, taking Shirakawa- go's predominent wind direction into account and minimizing wind resistance, while controlling the amount of sunlight hitting the roof, to provide cool summers and warmer winters. Each house has at least three to five stories to ensure that there was enough space to 
store farming or sericulture equipment. Due to its rural location in the rugged mountains of Northern Gifu, Shirakawa-go was extremely isolated up until the 1950s, therefore the traditions and farming techniques are rather unique to the area. There are many houses that are still inhabited by local families but also double up as museums, with Kanda House being a prime example. The straw from crops is used to thatch the roof. The material used to thatch the roof is acquired in the autumn. It is dried and used as a snow fence around the Gassho-style house. Rethatching of the roof is done either in the spring or autumn.

In Japanese architecture, the transitional boundaries that form the buildings enclosure are synthesized as intermediate spaces and screenings (Kuma 2010). Older Japanese houses tend to have a raised wooden veranda that runs around the outside edge of the house. This is called an engawa and is like an outdoor corridor. The engawa transitional space is located at lower or similar floor level as the interior areas, paved by different materials as pebbles or wood board flooring. It is enclosed by different mutable gradations which is wide open, translucent panels and/or opaque shutters, acting as intermediate thermal insulation and ventilation space. Another characteristic of the Gassho-style houses are that the structure and uses are different between the first floor and the attic. The attic is two stories high. The bottom floor of the attic is called "Ama" and the top floor of the attic is called "Sora-ama". Generally, Japanese style houses contain a pillar in the attic, which restricts the use of the attic. However, there is no need for a pillar in the attic of the Gassho-style houses. The first floor is constructed first, the attic next.

\section{Supporting Facilities}

Kampung Morten consists of 96 traditional houses with 13 of them offer kampong-style accommodation. Even though the area might not provide accommodation such as motels or hostel, but, tourist can experience of living in a traditional Melaka village and explore the local lifestyle. While in Ogimachi Village, the village provide a small motel for tourist to stay for a couple of days. But the number of motels and rooms are very limited since the area are strictly controlled by the tourist daily arrival. Tourists can experience to be stayed in Gassho-style house while enjoying the great view of Mount Hakusan. Therefore, these two heritage villages have provided few supporting facilities purposely to serve the tourists for better services.

Kampung Morten is a famous tourist spot in Melaka, however the area does not have any tourist information center. The tourists may acquire basic information pertaining to the village in Villa Sentosa, the only living museum that showcase Malay traditions and decorations of a traditional Malay house. While the information centre in Ogimachi Village is located nearby bus terminal. Kampung Morten is a historical village and inherit, because of that, facilities for visitors in that area are not fully provided by local authority or even by local residents. Hence, there is no public toilets for the tourists. Meanwhile, in Ogimachi Village, a building was built by the Shirakawa-go Tourism Association and renovated to provide a rest and information facility for visitors. New public toilets were also constructed to the south of the rest area. The facility's name, "Yururi", is the word for "hearth" in the local dialect. The word combines three Japanese words linked by the symbolism of Gassho-style houses. "Yukkuri", meaning unhurried, "Yuttari", to relax, and "Irori", Japanese for "hearth". The village has provided a designated toilets and public toilets with auto water supply equipment as they have strict rules on cleanliness for the villages. Other than public toilets, Ogimachi Village also provide facilities such as rest area where wooden benches installed, and they also provided breast feeding and baby changing room. All the facilities were design for tourist convenient to visit and having good times visit the villages.

For street facilities, Kampung. Morten does not provide any specific parking lots in the area. But, tourist who visited the village using their own vehicles, they still can enter the village by their car, or they can park their car at the roadside. Other than that, other street facilities provided in Kampung. Morten are pedestrian walkway and lamp post. Alongside Melaka River, there is well-maintained pedestrian walkway supported by lamp post. Tourists can walk around the village while enjoying the view of Melaka River. While in Ogimachi Village, private vehicles is controlled by the authorities into 
the village in order to protect the environment and the safety of local people. Hence, they provide a centralized parking distance away from the village for buses and other private vehicles. The road and pedestrian facilities are disabled friendly where it is wheelchair access via ramp. Table 3 below is the summary of the supporting facilities for both heritage villages.

Table 3. Supporting facilities

\begin{tabular}{lcc}
\hline \multicolumn{1}{c}{ Component } & $\begin{array}{l}\text { Kampung Morten } \\
\text { Supporting facilities }\end{array}$ & Ogimachi Village \\
\hline Accommodation & $\square$ & \\
Tourist Information Centre & $\mathrm{x}$ & $\square$ \\
Public toilet & $\mathrm{x}$ & $\square$ \\
Parking Lot & $\mathrm{x}$ & $\square$ \\
Street facilities : & & $\square$ \\
a. Pedestrian & $\square$ & $\square$ \\
walkway & & $\square$ \\
b. Lamp post & $\square$ & $\square$ \\
\hline
\end{tabular}

Source: Site inventory, 2019

\section{Tourism Activities}

Ogimachi Village is a cultural tourism village that relies on tradition as tourist attraction. The existence of traditional Japanese house is an important asset for retaining its authenticity as a dwelling. There are 24 souvenir shops, 29 restaurants, and 24 accommodations surround the village. Each of this attractions and activities contributes toward Ogimachi village economic. Based on Jimura (2011), the activity that contributes to GDP of Ogimachi village is their transaction from souvenir shops. It was supported by Shinobu et al. (2014), the style of the houses attract tourist to get at least three souvenirs from Ogimachi village. This shows that the tourist is being attracted to the style of houses since they reach and have a glimpse of Gassho-style houses. On the other hand, Kampung Morten only provides homestay services as well as a living museum. Table 4 below shows the list of attractions for Kampung Morten and Ogimachi Village.

Table 4. List of tourist attractions in Kampung Morten, Melaka

\begin{tabular}{ll}
\multicolumn{1}{c}{ Components } & \multicolumn{1}{c}{ Tourists' Attractions } \\
\hline Villa Sentosa & $\begin{array}{l}\text { Villa Sentosa is one of } 90 \text { traditional houses and it is the most attractive } \\
\text { and best preserved of all the houses in Kampung. Morten and it now } \\
\text { serves as a private museum and is open to the public. It is known as The } \\
\text { Malay Living Museum. }\end{array}$ \\
- Homestay program & $\begin{array}{l}\text { - Business, entrepreneurship and enterprise activities is small scale } \\
\text { - "Act and Think Tourism" program }\end{array}$
\end{tabular}

Source: Site inventory, 2019 
Table 5. List of tourist attractions in Ogimachi Village, Shirakawa-go

\begin{tabular}{ll}
\hline Components & \multicolumn{1}{c}{ Tourists' Attractions } \\
Wada house & $\begin{array}{l}\text { The house was built in Edo Period (1603-1868) and has been designated } \\
\text { as Important Cultural Properties. Wada house is the well-preserved and } \\
\text { representing largest gassho style in Shirakawa-go, There are a variety of } \\
\text { artifacts and traditional everyday items used by successive generations of } \\
\text { the Wada family are exhibited. }\end{array}$ \\
Kanda House & $\begin{array}{l}\text { The house is a dignified gassho style and was constructed in around } 1850 . \\
\text { as the floor plan and long roof beams. }\end{array}$ \\
Shirakawa Kaido & $\begin{array}{l}\text { There are many souvenir shops and stalls offering portable snacks along } \\
\text { the street. }\end{array}$ \\
Street &
\end{tabular}

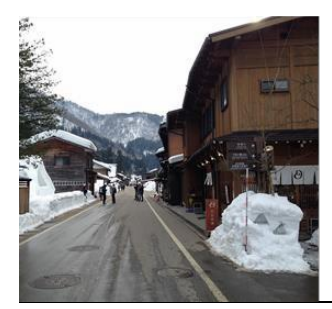

Deai-Bashi

Suspension Bridge

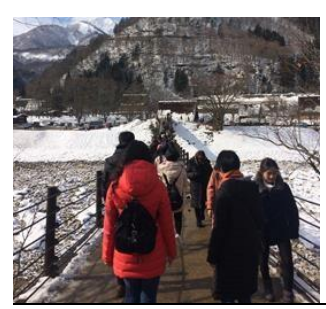

Gasshozukuri Minkaen Outdoor Museum

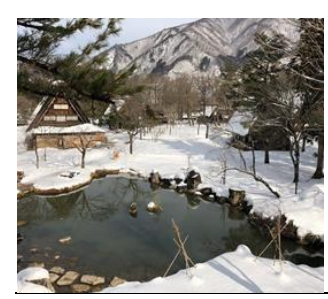

This bridge, serving as the entrance to the Shirakawa-go village. It is also a place where you can enjoy one of the best panorama spot of the village, mountains and river. 


\begin{tabular}{ll}
\hline $\begin{array}{l}\text { Shirakawa Hachiman } \\
\text { Shrine }\end{array}$ & $\begin{array}{l}\text { Hichiman Shrine is Shinto shrine where the Doburoku Matsuri is held } \\
\text { every year from September to October. }\end{array}$
\end{tabular}

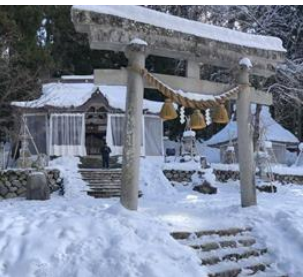

Myozenji Temple and House

Myozenji Temple, which is unique for its thatched roof rather than the

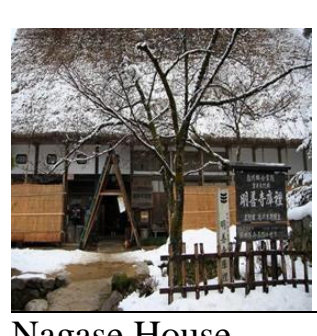
typical tiled roof seen on most temples, is connected to the Myozenji-ke farmhouse next door where the priest of the temple lives.

Nagase House

The Nagase residence has been passed down within the Nagase family

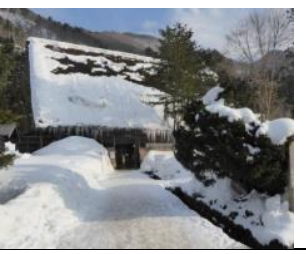
for 250 years. The first three generations to occupy the house were doctors and the house now exhibits medical equipment from the Edo Period.

\section{Ogimachi Castle} Observation Deck

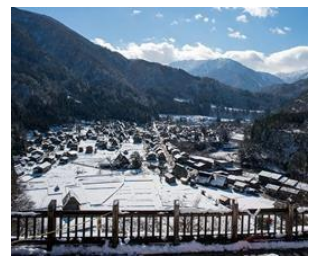

It is a popular photo spot as it overlooks the "Gassho-Zukuri" houses in every season, including views of its greenery, the autumn leaves, and covered in snowfall.

Source: Site inventory, 2019

\section{CONCLUSION}

Conserving the heritage villages is an essential effort in sustaining the irreplaceable historical values. The significance of the world heritage site lies in its ability to retain the authenticity of its heritage value and the uniqueness of its townscape character. The protection of the urban landscape elements will help to sustain the character of the UNESCO's World Heritage Sites. This is done by identifying the heritage physical elements that are created by human interactions with their environment and also helps to define the character of a community (local) as well as reflecting its past seems to be the most important thing to achieve in any conservation process. In order to have a more effective conservation of historic towns and areas, historic urban landscape should become an integral part of the coherent policies of economic and social development and of urban and regional planning actions at every level. 


\section{REFERENCES}

Adie, B., Ashton, M., Hall, C., \& Girish, P. (2018) World Heritage as a placebobrand: a comparative analysis of three sites and marketing implications. Journal of Sustainable Tourism, 26 (3), 399415.

Butrina, P., Vine, S.L., Henao, A., Sperling, J., \& Young, S.E. (2020). Municipal adaptation to changing curbside demands: Exploratory findings from semi-structured interviews with ten U.S. cities. Transport Policy, 92, 1-7

Canale, R.R., Simone, E.D., Maio A.D., Parenti, B. (2019). UNESCO world heritage sites and tourism attractiveness: The case of Italian provinces. Land Use Policy, 85, 114-120.

Carbone, F. (2016). An insight into cultural heritage management of tourism destinations. European Journal of Tourism Research, 14, 75-91.

Frey, B.S., \& Steiner, L. (2011). World Heritage List: does it make sense? International Journal of Cultural Policy, 17 (5), 555-573.

Government of Japan (1950) Law for the Protection of Cultural Properties.

Government of Japan (1977) Law for the Protection of Cultural Properties. Cultural Properties Protection Department, Agency for Cultural Affairs.

Indera Syahrul, Naoko F., \& Yahaya Ahmad. (2014). Cultural heritage, incentives system and the sustainable community: Lessons from Ogimachi Village, Japan. Malaysian Journal of Society and Space, 10, $130-146$.

Ismail, M. (1992). Rumah Tradisional Melayu Melaka. Persatuan Muzium Malaysia. Kuala Lumpur: United Selangor Press Sdn.Bhd., 7-18.

Jimura, T. (2011). The impact of world heritage site designation on local communities: A case study of Ogimachi, Shirakawa-mura, Japan. Tourism Management, 32(2), 288-299.

Kim, S. S., Wong, K. K. F., \& Cho, M. (2007). Assessing the economic value of a world heritage site and willingness-to-pay determinants: a case of Changdeok Palace. Tourism Management, 28 (1), 317- 322.

Shinobu, Y.Y, Yasunori, K., Jun-ichi, T., \& Katsuyuki, H. (2014). Integrated Conservation Approach: A Case Study of Shirawa-Mura in Japan. Tourism Management, 32, 288-96. 